Pregledni članak UDK 1 316.423.3(045)

doi: 10.21464/fi40109

Primljeno 1. 1. 2019 .

\title{
Lana Zdravković
}

Mirovni inštitut, Metelkova 6, SI-1000 Ljubljana

lana.zdravkovic@mirovni-institut.si

\section{Misliti revoluciju kao stvaranje univerzalnog - neetatističkog, nepredstavničkog, neidentitetnog - prostora politike »za sve«}

\section{Sažetak}

\section{Ključne riječi}

revolucija, misao-praksa, emancipacijska politika
\end{abstract}

U radu se razmatra mogućnost mišljenja i prakticiranja revolucionarne politike u suvremeno doba, kroz osvrt na nasljeđe revolucionarne misli-prakse 20. stoljeća te revolucionarne događaje u 21. stoljeću koji eksperimentiraju s konstitucijom revolucionarne moći bez zauzimanja vlasti. Izlazeći iz povijesne situacije obilježene tvrdnjom da revolucija »jede svoju djecu«, tvrdim kako istinska revolucija ne znači preuzimanje vlasti, već suprotno, ukidanje instance koncentrirane moći. Revoluciju treba nanovo osmisliti te je postaviti na kartu povijesti kao emancipacijski proces uspostavljanja politike jednakosti, što znači stvaranje univerzalnog - neetatističkog, nepredstavničkog, neidentitetnog - prostora politike »za sve« odnosno za »bilo koga«, bez Drugoga. To pretpostavlja osmišljavanje i redefiniranje revolucionarnog subjekta, revolucionarne metode i revolucionarne organizacije.

\section{Uvod: misliti revoluciju}

Revoluciju, prije svega, treba ponovo izmisliti, tvrdili su još situacionisti (Situacionistička internacionala: 121), napuniti je subverzivnim, konfliktnim, emancipacijskim potencijalom. ${ }^{1}$ Vratiti joj politički naboj. Društvo je spektakla - kao »pogled na svijet koji se je materijalizirao« (Debord, 1967: 9), kao režim koji je »u isto vrijeme rezultat i cilj vladajućeg oblika proizvodnje « (Debord, 1967: 10) i kao »ništa drugo nego ekonomija koja se razvija zbog sebe same « (Debord, 1967: 12) - iskrivilo pojam revolucije do te mjere da se može reći da pojam djeluje još samo kao zavodljivi prazni označitelj koji uspješno pospješuje prodaju, reklamira proizvode i reproducira tržišnu logiku. Intenzivno makar posljednjih stotinu godina, što od prvog izdanja Marxova Kapitala iz 1867. godine i nije neka novost, marketing se - najprije na »razvijenom Zapadu«, a potom, kao posljedica uspješnog »širenja demokracije « i diljem svijeta - služi označiteljem revolucionarno pri prodaji svojih artikala. ${ }^{2}$ Problem nije sama upotreba riječi revolucija, već simptom na

1

Rad je djelomično rezultat znanstvenog projekta J5-1749 naslova »Prekid tradicije: Hannah Arendt i konceptualna promjena «, koji je financira slovenska istraživačka agencija.
2

Pomislimo samo na »revolucionarnu moć« rezanja britvice, upijanja uložaka ili usisavanja usisivača, a da »revolucionarnu tehniku « najnovijeg modela automobila, mobitela ili 
koji ta upotreba ukazuje, naime, na to da je revolucija postala samo još jedan od omamljivih čimbenika unutar dispozitiva kapitalizma. ${ }^{3}$ Radi se, dakle, o procesu vladanja - takvom, da se jedini neprestano revolucionira, a uz to uspješno razgrađuje osobne odnose, političku zajednicu i društvo kao takvo.

Iako je revolucija, po mom mišljenju, u svojoj istinski emancipacijskoj namjeri politička metoda temeljne promjene svijeta u smjeru radikalne jednakosti, što pretpostavlja ukidanje instance vlasti te politizaciju ljudske moći, potencijala i želje, dosadašnji nas revolucionarni pokušaji te današnje globalno brutalno antipolitičko stanje suočavaju sa spoznajom da je revolucija uglavnom talac dominantne kapitalističke ideologije. Kooptiranje revolucionarnih ideja od strane vladara opće je mjesto, a jedino vodi u perpetuiranje utvrđivanja nejednakosti. Francuska buržoaska revolucija (1789.) kao inspiracija mnogim sljedećim revolucijama završila je Robespierreovim terorom; Pariška komuna (1871.) ugušena je u krvi; Ruska revolucija (1917.) rezultirala je boljševičkim terorom i do kraja produbila jaz između komunista i anarhista; prvi rat protiv fašizma, Španjolski građanski rat (1936.) krvavo se je nastavio u Francovu diktaturu i Drugi svjetski rat. Revolucionarna teorija do sada nije uspjela do kraja dokučiti zašto revolucionarna praksa »jede svoju djecu«. Zato se ozbiljni revolucionarni projekt danas, koji, prije svega, mora biti strukturiran kao misao-praksa, po mom mišljenju, mora suočiti s kritičkim preispitivanjempromjenom svega, od međuljudskih odnosa, preko političke zajednice, do odnosa sa svijetom (prirode, životinja, resursa). To pretpostavlja izmišljanje-redefiniciju revolucionarnog subjekta, revolucionarne metode i revolucionarne organizacije. Revoluciju treba postaviti na kartu povijesti kao emancipacijski proces uspostavljanja politike jednakosti, što znači stvaranje univerzalnog neetatističkog, nepredstavničkog, neidentitetnog - prostora politike »za sve« odnosno za »bilo koga«, bez Drugog.

\section{Revolucionarna misao-praksa 20. stoljeća}

U duhu slavne 11. teze o Feuerbachu - FFilozofi su svijet samo različito interpretirali, radi se o tome da ga se izmijeni.« - Marx i Engels postavili su ideju komunističke revolucije kao jedan od najvažnijih političkih pojmova, koji vodi u besklasno društvo, odumiranje države i nestanak rada. Dosljedni metodi dijalektički materijalizma, revoluciju koncipiraju radikalno drugačije od prethodnika, i to kao revolucioniranje ne društva ili države, već, prije svega, produkcijskih odnosa.

»... komunistička revolucija se usmjerava protiv dosadašnjeg produkcijskog načina, uklanja rad i eliminira gospodstvo svih klasa samim klasama, jer je izvodi klasa, koja se u društvu više ne računa ni za kakvu klasu, nije prepoznata kao klasa i već je izraz demontaže svih klasa, naroda.« (Marx i Engels, 1975a: 47)

Jedina revolucionarna klasa - proletarijat - svoje oslobađanje može doseći »samo nasilnim svrgavanjem buržoazije« (Marx i Engels, 1975b: 601). Za Marxa i Engelsa je jasno da je jedina istinski bitna revolucija takva da donosi uništenje kapitalizma, makar morala uspjeti preko diktature proletarijata.

»Između kapitalističkog i komunističkog društva je period, u kome se prvo, revolucionarno preobražava u drugo. Tome je primjeren i politički prelazan period, gdje država ne može biti ništa drugo do revolucionarna vladavina proletarijata.« (Marx, 1975: 505)

Ta je ideja (s mnogobrojnim teorijskim modifikacijama, polemikama i račvanjima u okviru misli koju obično nazivamo marksizam) većinski prevladavala u revolucionarnoj praksi 20. stoljeća, ne samo u iskustvu Sovjetskog saveza, 
Jugoslavije i Kine nego i u mnogobrojnim borbama za nacionalno oslobođenje te u gerilskim pokretima država Južne Amerike, Azije i Afrike. Međutim, preobraženje iz kapitalizma u komunizam se - preko uspostavljanja socijalističkih država, putem vladavine partije i izjednačavanja radnika i državljana - nigdje nije zbilo, ni na način na koji su to predvidjeli Marx i Engels, ni na bilo koji drugi način.

Kritike su marksizma brojne, a u svrhu ovog istraživanja zanimale su me kritike koje za cilj imaju reinvenciju marksizma.

»Historijsko uništenje marksizma znači dakle njegovu smrt kao univerzalnog događaja političke misli.« (Badiou, 2004: 35)

Badiou, međutim, nije anti-marksist, naprotiv. Njegova filozofska kritika marksizma ovdje mi služi upravo kao poticaj na ponovnu kritičku afirmaciju vrijednosti koje ta ideja sa sobom nosi.

»Ako marksizam nije moguće braniti, to je zato što ga je treba ponovno započeti.« (Badiou, 2004: 41)

U današnjim je izrazito anti-marksističkim društvenim uvjetima istinsko revolucionarno pitanje kako reafirmirati tu emancipacijsku misao kojoj Badiou daje ime ideja komunizma, kao »jedinu dobru hipotezu « (Badiou, 2008: 97) na novim temeljima usprkos dosadašnjem neuspjehu pokušaja njenog otjelovljenja. Danas je bitno, ističe Badiou, izgraditi »nov odnos između realnog političkog pokreta i ideologije« (Badiou, 2008: 114), što znači da se treba baviti pitanjem realizacije, prezentacije i organizacije ideje komunističke hipoteze, koju treba razumjeti kao generičku ideju. Ključno je »kako se misao, koju usmjerava hipoteza, predstavlja u figurama djelovanja« (Badiou, 2008: 114). Te figure djelovanja svakako ne mogu više biti radnički pokret 19. stoljeća niti komunistička/socijalistička stranka 20. stoljeća, već treba izmisliti »nov modus egzistencije hipoteze« (Badiou, 2008: 116).

To je pitanje na svoj način otvarao i anarhizam ${ }^{4}$ (prije svega, anarho-socijalizam, anarho-kolektivizam i anarho-komunizam) koji ne samo da ima puno zajedničkih teorijskih točaka s Marxovom i Engelsovom analizom nego su anarhisti i komunisti mnogo puta bili zajedno na barikadama protiv zajedničkog neprijatelja: buržoazije. Anarhisti, međutim, kritički preispituju temelje Marxova i Engelsova nauka. Marksizam su tradicionalno kritizirali jer se je izrodio u autoritarnost i omogućio nastanak društva podložnog zloupotrebi (državne) moći.

»Liberalizam, socijalizam i državni komunizam tri su brata, koji svaki na svoj način teže k preuzimanju vlasti nad čovjekom, vlasti koja čovjeku onemogućava da se razvija u smjeru apsolutnog savršenstva, koji se dostiže u slobodi i nezavisnosti (...).«(Mahno, 1986: 499)

računala niti ne spominjem. »Revoluciju « nam, dakako, donosi i kozmetička (»revolucionarna moć« maskare), farmaceutska (»revolucionarna moć« tablete za mršavljenje i/ili erekciju) ili prehrambena (»revolucionarna moć« veganskog burgera) industrija.

Dispozitiv rabim u foucaultovskom smislu, kao »heterogeni skup koji virtualno uključuje sve jezično i nejezično, dakle, diskurse, institucije, zgrade, zakone, policijske mjere, filozofske propozicije itd. i uspostavlja se kao mreža među tim elementima; koji ima svagda određenu konkretnu stratešku funkciju i upisuje se svagda u odnose moći te koji kao takav proizlazi iz ukrštanja odnosa moći i odnosa znanja« (Foucault, 1980: 194-195).

4

U svakodnevnoj je upotrebi pojma anarhizam on još uvijek sinonim za kaos i nered, mada se kao društveno-filozofska i politička doktrina ideološki zapravo zauzima za pravedno, besklasno društvo, bez vlasti (an-arche). 
»Revolucionarna vlast« za anarhiste je jednostavno nemogući spoj, »to su dva koncepta koji su jedan s drugim u suprotnosti i koji jedan drugog ukidaju« (Kropotkin, 1986: 305). Bakunjin je pisao o »buržoaskom socijalizmu « (Bakunin [Bakunjin], 1986a: 252) te kritizirao koncepciju proletarijata koji se uspostavlja kao klasa, a ne kao mnoštvo (Bakunin [Bakunjin], 1986a: 252) i na taj se način ne odnosi na sve, već samo na radnike.

Od marksista se anarhisti razlikuju i po drugačijem razumijevanju same revolucije.

»Svrgnuti režim - to je glavni cilj buržoaskog revolucionara. Za nas je to tek početak društvene revolucije.« (Kropotkin, 1986: 304)

Revoluciju anarhisti ne poimaju kao promjenu odnosa moći 'preko noći' ili putem opozicije, već kao proces, kao dosezanje promjena neprestanim aktivnim djelovanjem i promocijom alternativnih oblika udruživanja, organizacije, angažmana.

»Što, dakle, mi anarhisti mislimo s revolucijom? Ne radi se o jednostavnoj promjeni političke vlasti. Revolucija znači da ljudi uzmu u svoje ruke sve društveno bogatstvo. Znači eliminaciju svih vladajućih sila, koje su uvijek onemogućavale razvoj čovječanstva.« (Kropotkin, 1986: 311)

»Temeljni spor « marksista i anarhista i neuralgična točka kritike svakako je pitanje države jer anarhizam, koji »danas nije samo najrevolucionarniji tok, već prvi put u historiji uopće jedini preostali« (Vodovnik, 2011: 9), za razliku od marksizma nikada nije imao ambiciju osvojiti državnu vlast:

»Ako je njihova država istinska ljudska država, zašto ju onda treba odbaciti, a ako je odbacivanje države potrebno za istinsko oslobođenje ljudi, odakle im onda toliko hrabrosti da je nazivaju ljudskom?«(Bakunin [Bakunjin], 1986b: 260)

Umjesto tvrde državne strukture, političku zajednicu zamišljaju kao autonoman i fluidan oblik zajedničke organizacije života bez hijerarhije i okorjelosti, kao komunu, asocijaciju (radnika, studenata, stanovnika), kao 'sovjet' (usp. Rizman, 1986: 28). Vrhovni im je primjer komune predstavljala Pariška komuna (1871.), gdje je zaživjela samoorganizacija i gdje su važili napredni zakoni koje je Francuska službeno uvela tek nekoliko desetljeća kasnije, npr. pravo glasa za žene, zabrana dječjeg rada i dijeljenje Crkve i države. Ona je i za Marxa predstavljala prvu pobunu autonomnog proletarijata (Marx, 1950), no kasnije je tu ideju odbacio za potrebe centralizirane vladavine partije. Koncepcija sovjeta naslanjala se na boljševički moto »Sva vlast sovjetima!«, kojeg su anarhisti uzeli ozbiljnije nego sami boljševici. Umjesto u osvajanje države anarhisti, dakle, vjeruju u decentralizirano samoupravljanje koje se temelji na samoorganizaciji te se realizira kroz participativnu/direktnu demokraciju/akciju. I to zato što državu ne razumiju kao mjesto koncentrirane moći i posljedično nečega što bi bilo moguće uništiti ili promijeniti revolucijom ili reformom, već kao niz odnosa među ljudima, kao način ljudskog ponašanja. Zato je, za anarhiste, državu moguće uništiti ili preoblikovati u istinsku političku zajednicu samo uvođenjem i prakticiranjem drugačijih, egalitarnih, odnosa: anarhističko razumijevanje moći, suverenosti i vlasti više je foucaultovsko, nego što je marksističko.

Anarhističku su misao-praksu nadogradili situacionisti u svojoj lucidnoj kritici modernih oblika dominacije i alijenacije, kako kapitalizma tako i marksizma. Ne samo da su bili glavni obješenjaci svibnja 1968. već su ga, svojim djelovanjem, u velikoj mjeri i pripremili. Njihova ideološka podloga zacrtana je bila kroz teoretiziranje spektakla kao dispozitiva, koji jednakost razumije kao jednakost u potrošnji (jednaki smo, prije svega, kao potrošači). 
»U početnoj fazi akumulacije kapitala 'politička ekonomija vidjela je proletera isključivo kao radnika', koji samo želi osigurati minimum uvjeta potrebnih za održanje svoje radne snage, nikada ga ne promatrajući iz perspektive 'njegove ljudskosti i slobodnog vremena'. Ta perspektiva vladajuće klase uskoro je bila revidirana: sve veće obilje roba dostiglo je nivo koji je zahtijevao višak kolaboracije radnika. Sada, na kraju radnog dana, na radnike se više ne gleda s prezirom, koji je ranije tako očigledno bio prisutan u svim aspektima organizacije i održavanja proizvodnje; na njih se sada gleda kao na odrasle osobe, s puno ljubaznosti i predusretljivosti, u skladu s njihovom novom ulogom, ulogom potrošača. Humanizam robe preuzima nadležnost nad radnikovom 'ljudskošću i slobodnim vremenom', naprosto zato što politička ekonomija sada može i mora preuzeti potpunu dominaciju nad tim sferama, i to baš kao politička ekonomija. 'Usavršeno poricanje čovjeka' tako preuzima vlast nad cijelom ljudskom egzistencijom.« (Debord, 1967: 18)

Njihov je cilj bio radikalna društvena promjena koju su razumjeli kao neprestani proces »proizvođenja situacija « (usp. Debord, 1967) i »revolucioniranja svakodnevnog života« (usp. Vaneigem, 1965). Na taj su način poručivali da revolucija nije nešto udaljeno, sveto, mistično, što će odraditi netko drugi, već započinje na razini drugačije organizacije života, koja se odupire dominantnoj organizaciji preživljavanja. Njihov je cilj zato bio probuditi u svakom čovjeku subverzivnu aktivnost koja bi na razini svakodnevnog života poticala uklanjanje konstantnih ograničenja »normalnosti « koje nameće dominantni društveni red sa svojim ideološkim i represivnim aparatima države. U tom se smislu kod situacionista nije išlo za nekim univerzalnim manifestom, programom ili planom - čemu su bili naklonjeni kako marksisti tako i anarhisti - već za spontanim buđenjem kreativnosti, imaginacije i djelovanja svakog čovjeka za potrebe slobodnog konstruiranja cjelokupnog vremena-prostora vlastitog života, kao buđenja istinskih strasti, potreba i želja.

»Revolucija nije nešto što ljudima 'pokazuje' kako da žive, već ono što ih čini živim.« (Situacionistička internacionala: 114)

Svibanj 1968. predstavljao je zadnji veliki revolucionarni »događaj« ili »situaciju « 20. stoljeća koja je za cilj imala pokušaj obnove ideje komunizma. »Miroljubive revolucije« 1989. godine u Srednjoj i Istočnoj Europi (Poljska, Mađarska, Istočna Njemačka, Čehoslovačka, Bugarska, Rumunjska, Albanija) te ne tako »miroljubivi« raspad Sovjetskog Saveza i SFR Jugoslavije predstavljali su početak post-komunističkog razdoblja $i$ »tranziciju « u tržišno gospodarstvo i parlamentarnu demokraciju, to jest liberalnu ideologiju. Pad Berlinskog zida simbolički je označio potpunu globalizaciju ideologije kapitalizma, što neki nazivaju i »permanentno vanredno stanje « (usp. Agamben, 2004), »četvrti svjetski rat« koji se reproducira putem »doktrine šoka« (usp. Klein, 2007), ili »globalni permanentni rat« (usp. Kurnik, 2005).

\section{Revolucija kao emancipacijski proces uspostavljanja politike jednakosti}

Kratak osvrt na revolucionarnu misao-praksu 20. stoljeća pokazuje da revolucionarni izazov 21. stoljeća mora biti strukturiran oko pitanja instance vlasti, ali ne u smislu njenog zauzimanja već, upravo suprotno, u smislu njene učinkovite dekonstrukcije (Holloway, 2004: 26). Kao što je pokazao Foucault - u velikoj mjeri inspiriran lekcijama svibnja 1968. - vlast nije nešto što samo tlači i zatire, već ujedno nešto što proizvodi i stvara, vlast tek konstituira ono što bi trebao biti predmet represije. I još više, vlast je neodvojiva od čovjekovih najdubljih strasti i upravo zato ju je tako teško - i s jurišanjem na barikade gotovo nemoguće - pobijediti. 
»Užitak i vlast se ne isključuju, ne okreću se jedno protiv drugog, već se progone, prekrivaju i pokreću jedno drugo. Povezuju se pomoću kompleksnih i pozitivnih mehanizama bodrenja i huškanja.« (Foucault, 2010: 49)

Pojam vlasti tako nije moguće uopćeno jednačiti s nasiljem i represijom jer je u svojim efektima i taktici mnogo dublja od gole sile zabrane, koju država generira svojim ideološkim i represivnim aparatima.

»... pod vlašću treba prije svega razumjeti brojne odnose moći, koji su imanentni području na kojem se izvode i sastavni su dio njihove organizacije (...).« (Foucault, 2010: 89)

Glavni cilj revolucionarnih borbi zato ne smije biti napad na parcijalne institucije vlasti: grupe, elite, klase, već prije na samu tehniku, formu i strukturu vlasti.

»Individuum nije postavljen nasuprot vlasti; mislim da je jedan od njenih primarnih posljedica. Individuum je posljedica vlasti i istovremeno ili precizno koliko je ta posljedica ujedno i element njene artikulacije. Individuum koga je konstituirala vlast je ujedno i njen nosilac.« (Foucault, 1991: 33)

I budući da je i čovjek sam produkt vlasti, političko djelovanje mora biti postavljeno šire, kao volja za vlast preko napada na oblike i načine individualizacije te na ekonomiju odnosa vlasti (Foucault, 1991: 104).

Pobune, demonstracije i protesti, čak i oni koji su se nazvali ili bi se mogli nazvati revolucionarnim u 21. stoljeću ${ }^{5}$ su, iako čak i započeti revolucionarnim idejama (ili su barem u nekom svom dijelu sadržavali revolucionarne ideje), u najbolju ruku završili smjenom vlasti (promjenom vladara) te $s$ »novim svježim licima« nastavili s reprodukcijom kapitalizma u ideološkom, parlamentarizma u političkom i neoliberalizma u ekonomskom smislu, u svome više ili manje radikalnom obliku.

Zahtijevati vlast bez vlasti tako predstavlja svojevrstan skandal kako u teoriji i politici tako i u revolucionarnoj praksi. To što Rancière definira kao »početni skandal politike « (Rancière, 2005: 30) označava jedinstven režim politike jednakosti koji razglašava da politika ne može biti ništa drugo nego an arche, to jest odsutnost svake vladavine. U tom smislu ne postoji demokratska vladavina jer je svaka vladavina nepravedna već sama po sebi. Zato logika revolucionarnog procesa ne može biti logika preuzimanja, već samo logika eliminacije vlasti. Drugim riječima: kada logika vlasti postane logika revolucionarnog procesa, revolucija je propala. Povijesna borba između siromašnih i bogatih, to je borba za priznanje rancièreovskih »neubrojenih « odnosno »udio onih koji su bez udjela « (Rancière, 2005: 53), ultimativna borba politike i antipolitike - Rancièrovim izrazom »policije « (Rancière, 2005: 43) - i na taj način također borba za opstanak politike kao takve. Moć koja se generira u toj borbi potom je politička moć koja se izražava kao moć onih koji nemaju prirodni, podrazumijevajući temelj da vladaju, nad onima koji nemaju prirodni, podrazumijevajući temelj da su vladani. Vladavina najboljih, najmoćnijih ili najmudrijih tako nema nikakve veće težine i nije ništa pravičnija, osim ako nije vladavina jednakih.

Ako koncept vlasti razumijemo kao dijalektičan i kao nešto što stvaramo svi (Holloway, 2004: 28), onda je veoma važan korak razumjeti i da je život bez dominacije, moći i iskorištavanja moguć. Zato je u postupku »promjene svijeta bez borbe za vlast « (Holloway, 2004: 28) veoma važno graditi »područja protu-vlasti« (Holloway, 2004: 26) koja ne mogu biti ostvarena bez angažmana svih. Revoluciju tako razumijem kao emancipatorni proces uspostavljanja neetatističke, nepredstavničke, neidentitetne politike jednakosti, bez Drugog. 


\section{a) Neetatizam}

Revolucija ne može uspjeti pukim zauzimanjem države.

»To nam pokazuje kako teorijska refleksija tako i cijelo 20. stoljeće neuspjelih iskustava.« (Holloway, 2004: 25)

Revolucionarno zauzimanje državne vlasti nikada nije preoblikovalo državu u političku zajednicu jednakih. Država je zasnovana kao ekskluzivna zajednica državljana (nas) koja svoju suverenost gradi na procesu »homogenizacije imaginarne nacije « (Anderson, 1998: 14), odnosno »konstruiranja fiktivne etničnosti« (Balibar i Wallerstein, 1991: 96), gdje se »antropološke razlike ujedinjuju i smještaju u odnose vlasti i diskursa (Balibar i Wallerstein, 1991: 96). Mitološkim narativom, ali i čisto realnim granicama, država je utemeljena na razlici od svih drugih (njih), strukturno se, dakle, uspostavlja na isključivanju i sistematično proizvodi Drugog: migranti, stranci, manjine, samo su najizrazitiji (i obično najranjiviji) simptom tog režima koji se u određenoj situaciji može proširiti i na sve ostale od kojih država nema koristi: žene, maloljetnici, supkulture, bolesni, invalidi, nezaposleni, lijeni, aktivisti, LGBTIQ. Za te se potrebe država služi strukturnim, simboličkim i objektivnim nasiljem (Žizek, 2007: 7) te preuzimanjem monopola nad legitimnom upotrebom sile producira točno određene subjekte koji odgovaraju balibarovskoj »normalnosti« (Balibar, 2004: 404).

Osnovni je problem države taj da je nacionalizam njena generička organska ideologija, koja se širi u mnogim smjerovima, odnosno:

»Suvremeni nacionalizam tako nam se otkriva prije svega kao konglomerat neokolonijalizma, neoimperijalizma, etnocentrizma i rasizma; pojmova koji su međusobno usko povezani i prepliću se.« (Balibar i Wallerstein, 1991: 37)

Uz to se, barem zadnjih trideset godina, socijalni elementi države uspješno razgrađuju te ona sve više postaje »lokalni upravitelj globalnog kapitalizma« (Badiou, 2015: 17), što pretpostavlja neprestani (ekonomski) rast koji se ne obazire ni na ljude, a kamoli na životinje, prirodu, resurse. Država je, dakle, »sama po sebi apolitična« (Badiou, 2004: 74).

Rekonstrukcija politike, kao najvažniji zadatak revolucije, može proizaći jedino iz neovisnosti od države, odnosno njene temeljne rekonstrukcije u smjeru istinske političke zajednice temeljene na principu jednakosti, bez Drugog.

»Danas je potrebno aktualizirati, a ne prorokovati nezavisnost politike u odnosu na nasilje države i ujedno i dalje pripisivati hipotezu radničkim i ljudskim događajima.« (Badiou, 2004: 72)

Emancipacijska misao-praksa (pretežno pod utjecajem anarhizma i situacionista) navodi primjer sovjeta, asocijacije, komune, kao »pozitivni eksperiment, čije mogućnosti još nisu u cijelosti sagledane i ostvarene« (Situacio-

Npr. protesti u Srbiji protiv Slobodana Miloševića 2000. - 2005. godine, Revolucija ruža u Gruziji protiv Eduarda Sevarnadzea 2003. godine, Ukrajinska narančasta revolucija protiv Viktora Janukoviča 2004. - 2005 godine, Druga kirgistanska revolucija protiv Kurmanbeka Bakijeva 2010. godine, Arapsko proljeće (Tuniska revolucija protiv Zinea El Abidinea Ben Alija 2010. - 2011. godine, Egipatska revolucija protiv Hosnija Mubaraka 2011. godine, Libijski vojni sukob u kojem je ubijen Moamar al-Gaddafi 2011. godine,
Sirijski vojni sukob protiv Bašara al-Asada koji traje od 2011. godine do danas, Jemenska revolucija protiv Alija Abdullaha Saleha 2011. godine), dugotrajni vojni konflikti u Iraku (2011. - 2013. godine), dugotrajne pobune u Grčkoj (2010. - 2012. godine), Španjolskoj (2011. - 2015. godine), Sloveniji, Hrvatskoj, Srbiji, Bosni i Hercegovini (2012. - 2013. godine) protiv mjera štednje, Ukrajinska revolucija protiv Viktora Janukoviča (2014. godine) itd. 
nistička internacionala: 151). Relativno noviju koncepciju predstavlja ideja »oslobođene«, »privremene autonomne zone«, kao »piratske utopije« koja može postojati u geografskom, socijalnom, kulturnom ili imaginarnom prostoru (Bey, 1985: 77).

\section{b) Nepredstavništvo}

Revolucija ne može uspjeti reprodukcijom predstavništva. Predstavnička politika zasnovana kao pregršt 'lijevih' i 'desnih' političkih stranaka, koja se utemeljuje prebrojavanjem glasova, generira »kapital-parlamentarizam « (Badiou, 2006: 239) u kojem se političke stranke zapravo jako malo razlikuju među sobom jer su zastupnice interesa kapitala, a ne ljudi i temeljne jednakosti. U tom je »parlamentarnom fetišizmu koji zamjenjuje 'demokraciju' " (Badiou, 2008: 3) pluralizam mišljenja homogeniziran, svaka je mnogostrukost pragmatično i utilitarno unificirana i klasificirana, a dobrobit je zajednice podvrgnuta profitabilnim i tehnokratskim interesima društvenih elita. Politička je participacija ograničena na izbore kao »praznik demokracije«, političku bi jednakost trebalo omogućavati pravo, a sve zajedno bi trebali pokretati ekonomski interesi i konkurentnost. U biti, sav taj parlamentarni »cirkus « zapravo estetizira proces utvrđivanja globalnog gospodstva koje je zasnovano na fenomenu »straha mnoštva« (Balibar, 2004: 55). Kao što pojašnjava Balibar - koji ove uvide temelji na Spinozi - to je dvojni, objektivni i subjektivni strah:

»To je strah koji osjeća mnoštvo. Ali je to također strah koji mnoštvo ulijeva svakome tko se nađe na položaju vlasti ili politički djeluje, dakle državi kao takvoj.« (Balibar, 2004: 56)

Taj, u sebi kontradiktoran, strah mnoštva ne može se razriješiti putem predstavništva jer

»... ako se vladari boje mnoštva zbog njegove prirode, zbog čega vlast u praksi nikada nije apsolutna, kako onda prijelaz u demokraciju barem malo omogućava da se mnoštvo na vlasti neće bojati samo sebe?«(Balibar, 2004: 78)

To pitanje otvara i Rancière koji detektira da je »postdemokracija « (Rancière, 2005: 119), kao samolegitimizirajuća praksa upravljanja, demokracija bez demosa: vladavina s ljudima u imenu, a bez njih. U situaciji »poklapanja bez ostatka između forme države i stanja društvenih odnosa « (Rancière, 2005: 119) dolazi do ukidanja ljudstva kao osnove demokracije, što neumitno vodi k ukidanju politike kao takve. Ni jedna reprezentacija ne može obuhvatiti rousseauovski »opći interes « jer je u koncepciji predstavništva »ljudstvo« reducirano na pasivnog promatrača odnosno konzumenta »politike«. Njegova je jedina »politička« gesta ta da delegira svoj »laički« glas »profesionalnim« političarima, odnosno voditeljima.

Politika bitno ne može biti reprezentirana - može se samo ostvarivati, provjeravati i prakticirati. Kao živa ideja radikalne jednakosti nereprezentabilna je. Budući da je osnovna zadaća spektakla pasivizacija -

»Ništavnost spektakla je utemeljena prisilom svojih promatrača - pasivnih agenata - da sudjeluju u njemu.« (Vaneigem, 1965: 59)

- borbu protiv predstavništva moguće je strukturirati jedino političkom direktnom akcijom koja izlazi iz svijesti da je i koncepcija ljudstva u sebi kontroverzan pojam. Emancipacijska misao-praksa znači svakodnevnu konstrukciju situacija »na ruševinama modernog spektakla « (Situacionistička internacionala: 76), koje će probuditi političku moć svakog pojedinca. Metoda samoorganizacije u ovakvoj konstelaciji također se temelji na anarhističkom i si- 
tuacionističkom nasljeđu i realizira se kroz narodne skupštine, koje najbolje funkcioniraju u manjim grupama, npr. u lokalnim samoorganiziranim zajednicama, koje nastaju tamo gdje živimo, studiramo ili radimo: na sveučilištu, radnom mjestu, u mjesnoj zajednici (usp. De Cleyre, 2011).

\section{c) Neidentitetnost}

Revolucija ne može uspjeti ako se odvija u ime određene (bilo koje) identitetne skupine. Identitetni princip temelj je kapitalističke društvene organizacije, odnosno liberalne ideologije koja konceptima multikulturalizma, tolerancije i prihvaćanjem Drugog maskira brutalnu strukturnu nejednakost. Humanitarnost na kojoj se temelji kapitalistička društvena veza, odnosno liberalizam sušta je suprotnost »uzajamnog prepoznavanja, zajedništva, prijateljstva i ljubavi« (Holloway, 2004: 67), to jest, radikalne jednakosti bez Drugog. Dominantni sistem pojedinca ne tretira kao dio »beskonačne mnoštvenosti« (Badiou, 2006: 241), već operira samo na dijelovima populacije odnosno »pod-mnoštvenostima« (žene, muškarci, studenti, mladi, zaposleni, nezaposleni, migranti, stranci, manjine itd.). Identitet, dakle, uvijek implicira neku definiciju koja pretpostavlja neku razliku među ljudima i tako se određene pod-mnoštvenosti održavaju unutar umjetno iskonstruiranih granica kulture, tradicije, etnije, nacije, naroda i/ili državljanstva.

U emancipacijskoj se borbi brišu granice identiteta. Istinska se politika ne dostiže u imenu prepoznavanja određene identitetne skupine, već u imenu svih, odnosno bilo koga:

»... u emancipacijskoj borbi se ne udružuju kulture u njihovom identitetu; u zajedničkoj borbi se udružuju 'potlačeni', iskorištavani, namučeni dijelovi svake kulture.« (Žižek, 2007: 142)

»Mi koji želimo promijeniti svijet ne možemo biti definirani.«(Holloway, 2004: 62)

Za istinsku politiku emancipacije tako nijedna »pod-mnoštvenost « nije važnija od bilo koje druge, politika emancipacije poznaje samo mnoštvenost kao univerzalno ime svih. Istinski revolucionarna gesta tako pretpostavlja konstrukciju »beskonačnog generičkog mnoštva« (Badiou, 1999: 174), »gdje pripadnost tom mnoštvu, to jest, biti njegov element, ne izvire ni iz jednog identiteta, nijedne posebne osobine « (Badiou, 1999: 174). Znači, ta je mnoštvenost bez poteza razlikovanja, bez hijerarhične raspoređenosti, bez identitetske dominacije.

U spektaklu se gubi jedinstvo svijeta (Debord, 1967: 15), zato moramo sve svoje moći usmjeriti u to da na svijet ne gledamo samo kao na mjesto čovjekove egzistencije, već također kao na mjesto permanentne političke borbe, u kojoj stalno teče verifikacija aksioma jednakosti bilo kakvog govornog bića s bilo kojim drugim govornim bićem. U tome je smisao i Badiouove izjave da »postoji samo jedan svijet « (Badiou, 2008: 51). U tom smislu jedinstvo svijeta nije jedinstvo brojeva, tržišta i profita, već jedinstvo »živih i aktivnih tijela sada i ovdje « (Badiou, 2008: 61). Takvo razumijevanje jedinstva svijeta nužno implicira otkrivanje istosti u Drugom i drugosti u Istom, što znači otklanjanje svih razlika, koje su za emancipacijsku politiku potpuno irelevantne. Odnosno, kako su ispostavljali situacionisti:

»Oni koji ne mogu vidjeti sebe u drugima osuđeni su da zauvijek ostanu strani samim sebi.« (Vaneigem, 1965: 103)

Istinski revolucionarni subjektivitet zato se mora obračunati s kultom vođa, s predvodnicima i licima revolucije i svoje djelovanje oblikovati kolektivno, 
horizontalno i univerzalno te afirmirati politički prostor gdje se pojedincima neće pripisivati magične, božanske i nadljudske moći.

\section{Subjekt revolucije: bezimeni}

Kao ostvarivanje politike emancipacije revolucija je, prije svega, stvar subjekata, načina subjektivizacije. A svaka subjektivizacija je, kako pokazuje Rancière, u biti dezidentifikacija ili deklasifikacija (Rancière, 2005: 51). Politička subjektivizacija iznova razdjeljuje iskustveno polje koje je svakome podjeljivalo njegov identitet, njegovo mjesto i njegov dio; radi se o procesu formiranja jednog, koji nije u relaciji samo sa sobom samim već je u relaciji s drugima.

»Prije nego konstrukcija identiteta to je ukrštanje identiteta, koje se odnosi na ukrštanje imena: imena koja povezuju oznake grupa i klasa s imenima ne-grupa i ne-klasa, postojeće s nepostojećim odnosno s još-ne-postojećim. « (Rancière, 1995: 67)

To je uvijek nemoguća identifikacija, koja od strane onih koji je prakticiraju nikada ne može biti u potpunosti ostvarena. Uz to, ne radi se o tome da prestanemo biti to što jesmo, već se radi o tome da imamo određenu distancu od označitelja koje nam priljepljuje dominantni red. Tek tada možemo proizvesti efekt jednakosti bilo koga s bilo kim. Politički se subjekt tako pojavljuje u pukotini između dva identiteta - onog kojeg se odričemo i onog koji simbolički preuzimamo. Pritom ni jedan ni drugi nije posve »naš «.

Istinski politički subjekt treba misliti unutar političkog režima produkcije jednakosti kao generičkog i konstituirajućeg izvan dijalektike Istog i Drugog, oslobođenog bilo kojeg identiteta, kao »bilo koja singularnost « (Badiou, 2006: 249). Politički subjekt potencijalno može biti svatko tko kroz misaopraksu uključuje potencijalno sve. Ali on niti koga predstavlja niti koga zastupa. Također, ne postoji preferencijalno, posebno, privilegirano ime političkog subjekta, politički je subjekt bezimeni. Rancière opisuje:

»U politici subjekt nema konzistentno tijelo, već je prolazni akter, koji ima svoje trenutke, svoja mjesta, svoje prilike i za koga je karakteristično da izumi, u dvojnom značenju tih izraza, logičnom i estetskom, argumente $i$ demonstracije, zato da bi doveo ne-odnos u odnos i dao mjesto ne-mjestu.« (Rancière, 2005: 107)

Politički subjekt, kako tvrdi i Badiou, nije nikada unaprijed definiran, već se uvijek nanovo - »događajno« - oblikuje u svojoj akciji (Badiou, 1998). Dugo je vremena »proletarijat « bio privilegirano ime političkog subjekta. Ali je marksistička koncepcija zanemarivala činjenicu da je egzistencija unutar kapitalizma konfliktna i da u klasnoj borbi svi sudjelujemo na »obje strane« - radi se o antagonističkom procesu. Holloway pojašnjava:

»Ključno je razumjeti da kritika buržoaske misli nije samo kritika 'njih'. Također je, možda čak i prije svega, kritika 'nas', kritika buržoaske prirode naših pretpostavki i kategorija, ili konkretnije, kritika naše su-krivnje u reprodukciji kapitalističkih odnosa moći. Kritika buržoaske teorije je kritika razdvajanja subjekta i objekta u našem vlastitom razmišljanju.« (Holloway, 2004: 54)

Zato je bitno proletarijat misliti izvan konceptualizacije pred-konstituirane kategorije, kojoj se ili pripada ili ne pripada. Jer čim proletarijat počne odgovarati svojemu konceptu, dakle, postajati univerzalni politički subjekt revolucije »on tada više nije klasa, već mnoštvo« (Balibar, 2004: 187). ${ }^{6}$

»Klasna borba ne događa se među konstituiranim oblicima kapitalističkih društvenih odnosa: konstitucija tih oblika jest sama klasna borba.«(Holloway, 2004: 129) 
Budući da postojimo »protiv-i-u-kapitalu« (Holloway, 2004: 85), revolucija mora biti univerzalna, ne klasna. I »proletarijat sam ne smije više biti klasa: neka bude klasa-neklasa« (Balibar, 2004: 187).

»Samo dok smo/nismo radnička klasa je revolucija kao samo-emancipacija radničke klase pojmljiva.« (Holloway, 2004: 130)

Tako je cilj revolucionarnog projekta uspostavljanje političkog subjekta kao »bilo koga«, iznad klasne klasifikacije, a to su »svi oni koji nemaju moć nad vlastitim životima i svjesni su toga« (Knabb, 2013: 78).

\section{Metoda revolucije: zahtjev za biti}

Kao što zaključuje Jelica Šumič-Riha, za razumijevanje bilo kakvih pobuna ključno je razlikovati zahtjev za imati od zahtjeva za biti (Šumič-Riha, 2007: 90). U zahtjevu za imati izražavamo neki nedostatak koji ne možemo ostvariti sami i zato se obraćamo na neku instancu Drugog koji može, ako to hoće, taj zahtjev ispuniti. U takvom je zahtjevu Drugi uvijek latentno prisutan i pretpostavljen. Putem takvih se zahtjeva Drugi nužno ustoličuje u svojoj nadređenosti, potpunosti, neizbježnosti. Suprotno, u zahtjevu za biti od Drugoga ne zahtijevamo ništa, Drugi tu ne postoji jer taj zahtjev producira samo prostor u kojem jesmo. Drugi je ovdje anuliran kao instanca hijerarhije - zato je zahtjev za biti revolucionaran emancipacijski zahtjev. Zahtjev za biti nije ni najmanje nezavisan od dobre volje Drugog, upravo suprotno, u svojoj biti pretpostavlja upravo uzdrmavanje, odnosno u zadnjoj fazi nestajanje, brisanje Drugog.

»Naći svoj prostor u Drugom, ako ti taj nije već od početka dodijeljen, znači izbušiti rupu u Drugom, stvoriti si svoj prostor u Drugom. Zahtjev za biti se odnosi na cijelog Drugog, ili barem pretpostavlja da je cijeli, ali samo zato da bi pokazao njegov manjak, njegovu nekonzistentnost.«(Šumič-Riha, 2007: 90)

Budući da zahtijeva uništenje Drugog kao instancu hijerarhije, zahtjev za biti istinski je emancipacijski, revolucionaran. To je zahtjev za temeljnom jednakošću koju ne može ispuniti država, stranka ili vođa jer taj zahtjev u sebi implicitno sadrži zahtjev za uništenje svakog nadređenog, hijerarhičnog, autoritativnog Drugog i stvara situaciju u kojoj svatko preuzima su-odgovornost za cijenu slobode, za situaciju u kojoj je istovremeno i vladar i biva vladan. Suprotnost između zahtjeva za imati i zahtjeva za biti suprotnost je između borbe za više plaće i borbe za eliminaciju kapitalističkog društva na kojem se temelji ekonomska nejednakost; između borbe za vjenčanja istospolnih osoba i borbe za eliminaciju institucije braka, na čemu se temelji kontrola populacije u buržoaskom društvu; između borbe za prava manjina i borbe za eliminaciju koncepta manjina, koji omogućava dominantnost većine.

Razumljivo je, svaka vlast svaki zahtjev za biti želi banalizirati na zahtjev za imati jer samo na taj način može opravdati i očuvati svoj opstanak. Prihvatit će bilo kakav pa i radikalan zahtjev, odnosno proporcionalnu odsutnost točnog sadržaja samo ako je postavljen »u imenu nekog zajedničkog identiteta, pripadnosti nekoj zajednici koja je reprezentirana u redu Drugog « (ŠumičRiha, 2007: 91). Ali ono što država ni po koju cijenu ne može tolerirati je da bi singularnosti sačinjavale zajednicu a da se ne pozivaju na neki identitet.

Za izvrsnu analizu zablude klasične ljevičarske pozicije, koja u analizu proletarijata intervenira samo racionalnim elementima te zane- maruje psihološke i zato ne može razumjeti zašto proletarijat može biti preuzet od strane desnice usp. Reich (1981). 
»Ni po koju cijenu neće priznati status zahtjevu koji postavljaju 'bilo koje', dakle generičke singularnosti, koje izmiču svakom identitetu, svakoj pripadnosti zajednici. Priznanje zahtjeva singularnosti, naime, implicira razvezivanje svake društvene veze, razvezivanje koje stavlja pod znak pitanja upravo samog Drugog, čiji raison d'être jest da singularnosti raspoređuje po prostoru s obzirom na mjesta i funkcije.«(Šumič-Riha, 2007: 91)

Zahtjev za biti zato je bit politike emancipacije jer prije nego »za sve«zahtijeva prava za »bilo koga«, preko »mogućeg « koje nam nudi država, odnosno vlast, zahtijeva, dakle, »pravo bez prava, kojim se deklarira neka politička svijest« (Badiou, 2006: 240). To je singularni zahtjev koji pretendira na univerzalnu validnost. Najveću pukotinu u Drugom zato izaziva univerzalni zahtjev:

»... ono, što je za Drugog do te mjere nesnosno, neprihvatljivo, da na tu golu činjenicu iskazivanja zahtjeva odgovara silom, je ustrajavanje zahtjeva preko svakog konkretnog sadržaja zahtjeva.«(Šumič-Riha, 2007: 90)

Zato zahtjev za biti mora biti glavni zahtjev istinski revolucionarnoga projekta.

\section{Revolucionarna organizacija (kao proces)}

U situaciji kada je politička participacija u svojoj biti omogućena samo kao pasivno konzumiranje parlamentarne politike, a za svaki će pokušaj aktivni su-kreator politike izvan politički jalovog parlamentarizma biti oštro sankcioniran (taj proces ide od ismijavanja preko marginalizacije do kriminalizacije), pitanje osnivanja političke organizacije i posljedično kontinuiranog političkog djelovanja koje generira opstoj političke zajednice kao emancipacijskog projekta »za sve« postalo je ključno pitanje revolucionarnog procesa 21 . stoljeća.

U vrijeme »ponovnog rađanja historije « (Badiou, 2012: 63) - kako Badiou naziva recentne pobunjeničke događaje po cijelom svijetu - postalo je konačno jasno da stare strukture kao što su stranke, sindikati i nevladine organizacije nisu više nosioci političke moći (Kurnik, 2013: 14). Zato je nužna invencija »prostorno-vremenskog dispozitiva, koji bi aktivnije povezivao diskurs političke subjektivizacije s diskursom organizacije« (Mezzadra i Roggero, 2007). Emancipacijski pokreti po cijelom svijetu već desetljećima nude jasnu analizu današnjeg trenutka koji uključuje kako kritiku geneze kapitalizma, liberalizma i neoliberalizma, tako i jasnu kritičku analizu etatizma, predstavništva i identitarizma. Međutim, još uvijek nismo izmislili novu političku organizaciju, kao »intersekciju između ideje i događaja« (Badiou, 2012: 63) koja bi aktivno djelovala i poslije pobuna, mobilizacija i jurišanja na barikade te omogućavala prostor za trajni (ili barem trajniji) opstanak emancipacijskog potencijala koji se oslobađa u svakom koncentriranom trenutku bunta. Strah od strukture, koji je konstantan među emancipacijskim pokretima, strah je da će njena forma poroditi nove autoritarnosti, hijerarhije i dominacije. To je realan strah, ali s tim se strahom treba aktivno suočiti jer odustajanje od tog suočavanja vodi jedino u perpetuiranje ropstva. Invencija strukture posredovanja između svijeta i ljudi te njegovom promjenom tako ostaje bitna zadaća svih nas.

»Proces koji nazivam 'organizacija' je, dakle, pokušaj očuvanja karaktera događaja (intenzifikacija, smanjivanje i lokalizacija), i kada događaj kao takav više nema svoju prvotnu moć. U tom je smislu organizacija transformacija događajne moći u vremenitost, u subjektivnu latenciju gdje Ideja održava samu sebe. To je invencija vremena, čije su partikularne osobine uzete iz događaja, vremena, koji na neki način raspliće svoj početak. To se vrijeme onda može smatrati i 
vanjskim vremenom, u smislu da organizaciju nije moguće upisati u vrijeme diktirano od strane prethodnog svijeta. Tu imamo nešto što bismo mogli nazvati vanjskim vremenom Subjekta, Subjektom izuzetka.« (Badiou 2012: 70)

U svojoj analizi revolucije nešto slično tvrdila je i Arendt. Osim što je razlikovala socijalnu od političke revolucije, također je upozoravala na to da nije svako pružanje otpora nužno revolucija. »Cilj je otpora oslobođenje«, tvrdila je, »a cilj je revolucije konstitucija slobode« (Arendt, 2017: 146). Na primjeru Američke revolucije 1787. godine pokazala je da je revolucionarna konstitucija osnivanje novog političkog tijela:

»Revolucija je konstitucija slobode i nove vlasti u oba smisla te riječi, koliko naime ustav znači kako konstituciju tako i osnivanje novog političkog tijela.« (Jalušič i Komel, 2017: 325)

Krajem 1990-ih godina Zapatisti (Zapatistička vojska narodnog oslobođenja / Ejército Zapatista de Liberación Nacional - EZLN) u Chiapasu u Meksiku, Pokret seljaka bez zemlje (Movimento do Trabalhadores sem tierra - MST) u Brazilu te Pokret nezaposlenih radnika (Piqueteros) u Argentini, koji su se samoorganizirano (i da, naoružano!) počeli odupirati američkom (i globalnom) brutalnom neoliberalizmu, upalili su neko novo svjetlo u radikalnom, kolektivnom i autonomnom emancipacijskom djelovanju. I to ne samo u teoretskom - njihov je moto »Za nas ništa, sve za sve.« - nego i u čisto praktičnom smislu jer na svojem »oslobođenom teritoriju « već 30 godina uspješno organiziraju svakodnevni život bez interesa za preuzimanje državne vlasti. Uspostavili su vlastiti autonomni sistem proizvodnje, zdravstva, školstva i socijale te tako cijelom svijetu pokazali da je drugačiji - pravedniji - svijet moguć.

Danas, u vremenu kada se čini da su »čak i najistaknutiji revolucionari tiho izgubili vjeru da je revolucija zaista moguća « (Graeber, 2019: 11), pred očima nam se dešava nešto slično, ovoga puta na Istoku. Rožava (Zapadni ili Sirijski Kurdistan) od 2012. je godine de facto autonomno kurdsko područje u Siriji koje ne pretendira na državnu vlast te je izboreno oružanim sukobom. Boj, koji je trajao od 1970-ih, svoj je vrhunac doživio 2014. godine, kada su kurdski borci i borkinje pobijedili i sa svojih područja protjerali džihadiste Islamske države te time izazvali začuđenost ostatka svijeta. Od tada na svojem »oslobođenom teritoriju « prakticiraju politiku demokratskog konfederalizma koju je, pod nezanemarivim utjecajem misli Murraya Bookchina, libertarijanskog socijalista i ekologa (usp. Bookchin, 1982), svojom »Deklaracijom o demokratskom konfederalizmu u Kurdistanu« iz 2005. (usp. Öcalan, 2011) opredijelio Abdullah Öcalan, kurdski vođa, ljevičarski politički teoretičar, politički zatvorenik i jedan od članova utemeljitelja militantne Kurdistanske radničke partije (Partiya Karkerên Kurdistanê - PKK). Politika demokratskog konfederalizma djeluje na dvije razine, što je »s vidika revolucionarne teorije u nekim pogledima iznimno «(Graeber, 2019: 15). S jedne su strane demokratsko samoupravljanje slično parlamentarizmu, s političkim strankama, ministarstvima, sudovima, a s druge su strane strukture koje djeluju odozdo prema gore i aktivistički su uređene na osnovu narodnih skupština, »odnos moći između te dvije strukture je fluidan i u stalnoj redefiniciji (Graeber, 2019: 15).

Ovi primjeri predstavljaju svojevrstan politički unikum koji pokazuje da je prijelaz iz političke utopije u političku realnost radikalne jednakosti moguć. Na ljudima je da nadiđu stadij romantiziranja tih primjera te razmisle što se može napraviti u lokalnim situacijama. Potrebno je razmotriti puno toga, od pitanja oružja (militantnosti), preko metode uspostavljanja političkog kolektiviteta, do odnosa prema vlastitim privilegijama. To podrazumijeva domiš- 
ljanje određene političke discipline koja bi generirala moć ljudi i garantirala opstanak političke zajednice.

\section{Zaključak: politizacija svakodnevnog života}

U posljednjih najmanje deset godina primjećujemo različite pokušaje obnove emancipacijske politike, ponovno promišljanje ideje komunizma te vraćanje univerzalne važnosti ideji jednakosti. Nastaju ideje o političkoj internacionalnoj organizaciji kao što je Peta internacionala Samira Amina, ili DiEM25 Yanisa Varoufakisa, sve češće je i osnivanje (»ljevičarskih «) koalicija-stranaka-pokreta koji se međunarodno povezuju. Ali ako se ove ideje ne maknu s pozicije etatizma, parlamentarizma i identitarizma, a ni kult vođe im nije stran, ne možemo ih razumjeti kao revolucionarne. Zato organiziranost treba graditi drugačije, na mikro-razini, na razini želje i svakodnevnog života.

Kao što su tvrdili situacionisti, »rekonstrukcija života i obnova svijeta su jedna i ista želja« (Vaneigem, 1965: 47). Zato je početak svakog revolucionarnog procesa »revolucioniranje svakodnevnog života« (Vaneigem, 1965: 47). To znači politizaciju života i razumijevanje da politika postoji utoliko ukoliko je svi stvaramo zajednički. To razumijevanje zatim može voditi u invenciju istinske političke situacije koja će uključivati svakog, »bezimenog subjekta«, metodu »zahtjeva za biti« i organizaciju koja neće reproducirati kult »profesionalnih revolucionara«, vođa, heroja i kultnih ličnosti, već će biti doživljena kao proces koji se stvara zajednički. Taj će proces morati znati preoblikovati klasnu borbu tako da će koncept rada biti odbačen u korist prava na lijenost i nerad (usp. Black, 2009; Lafargue, 1980; Debord, 1967), da će promovirati kreativnost umjesto produktivnosti i dobar život umjesto reprodukcije. U tom procesu, u kojem su individualna i kolektivna razina nerazdvojno povezane, otvara se prostor za radikalnu promjenu nas i svijeta.

\section{Literatura}

Agamben, Giorgio (2004): Homo Sacer. Suverena oblast in golo življenje, preveo Samo Kutoš, Koda, Študentska založba, Ljubljana.

Anderson, Benedict (1998): Zamišljene skupnosti: o izvoru in širjenju nacionalizma, preveli Alja Brglez Uranjek, Andrej Kurillo, Studia humanitatis, Ljubljana.

Arendt, Hannah (2017): O revoluciji, preveli Mirt Komel i dr., Krtina, Ljubljana.

Badiou, Alain (2015): »Predavanje z dne 23. novembra 2015«, prevela Janina Kos, Filozofski vestnik XXXVI (2015) 3, str. 7-40.

Badiou, Alain (2012): The Rebirth of History, preveo Gregory Elliott, Verso, London.

Badiou, Alain (2010): The Communist Hypothesis, preveli David Macey, Steve Corcoran, Verso, London.

Badiou, Alain (2008): Ime česa je Sarkozy?, prevela Miranda Bobnar, Založba Sophia, Ljubljana.

Badiou, Alain (2006): Pogoji, preveli Samo Tomšič, Ana Žerjav, Založba ZRC, Ljubljana.

Badiou, Alain (2004): Ali je mogoče misliti politiko?; Manifest za filozofijo, preveli Rado Riha, Jelica Šumič-Riha, Založba ZRC, Ljubljana.

Badiou, Alain (1999): »Osem tez o univerzalnem«, prevela Jelica Šumič-Riha, Filozofski vestnik XX (1999) 1, str. 167-175.

Badiou, Alain (1998): Sveti Pavel: Utemeljitev univerzalnosti, prevela Alenka Zupančič, Društvo za teoretsko psihoanalizo, Analecta, Ljubljana. 
Bakunin [Bakunjin], Mihail (1986a): »Buržoazni socializem«, Antologija anarhizma 1, preveli Doris Debnjak i dr., Rudi Rizman (ur.), Krtina, Ljubljana, str. 251-254.

Bakunin [Bakunjin], Mihail (1986b): »Državnost i anarhija«, Antologija anarhizma 1, preveli Doris Debnjak i dr., Rudi Rizman (ur.), Krtina, Ljubljana, str. 255-263.

Balibar, Étienne (2004): Strah pred množicami: politika in filozofija pred Marxom in po njem, preveli Katarina Rotar, Alenka Zupančič, Studia Humanitatis, Ljubljana.

Balibar, Étienne; Wallerstein, Immanuel Maurice (1991): Race, Nation, Class: Ambiguous Identities, Verso, London.

Bey, Hakim (1985): T.A.Z.: the temporary autonomous zone, ontological anarchy, poetic terrorism, Autonomedia, New York.

Black, Bob (2009): The Abolition of Work, The Anarchist Library. Dostupno na: https://theanarchistlibrary.org/library/bob-black-the-abolition-of-work (pristupljeno 19. 1. 2020.).

Bookchin, Murray (1982): The Ecology of Freedom: The Emergence and Dissolution of Hierarchy, Cheshire Books, Palo Alto.

De Cleyre, Voltairine (2011): Direktna akcija, prevela Biljana Romić, DAF, Zagreb.

Debord, Guy (1967): Society of Spectacle, The Anarchist Library. Dostupno na: https:// theanarchistlibrary.org/library/guy-debord-the-society-of-the-spectacle (pristuplje $\overline{19}$. 1. 2020.)

Foucault, Michel (2010): Zgodovina seksualnosti, preveo Brane Mozetič, Založba ŠKUC Lambda, Ljubljana.

Foucault, Michel (1991): Vednost-oblast-subjekt, preveli Tomaž Erzar i dr., Krtina, Ljubljana.

Foucault, Michael (1980): »The Confession of the Flesh«, u: Power/Knowledge. Selected Interviews and Other Writings, Colin Gordon (ur.), Pantheon Book, New York, str. 194-228.

Graeber, David (2019): »Predgovor«, u: Anja Flach, Ercan Ayboğa, Michal Knapp (ur.), Revolucija v Rožavi: Demokratična avtonomija in osvoboditev žensk v sirskem Kurdista$n u$, Inštitut Časopis za kritiko znanosti, Ljubljana.

Holloway, John (2004): Spreminjamo svet brez boja za oblast: pomen revolucije danes, preveli Mirsad Begić i dr., Študentska založba, Ljubljana.

Jalušič, Vlasta; Komel, Mirt (2017): »Misliti revolucijo po Hannah Arendt ali politična znanost o ustanavljanju novih oblik vladavine«, u: Hannah Arendt, O revoluciji, preveli Mirt Komel i dr., Krtina, Ljubljana, str. 325-341.

Klein, Naomi (2007): The Shock Doctrine: The Rise of Disaster Capitalism, Knopf Canada, New York.

Knabb, Ken (2013): The Joy of Revolution, The Anarchist Library. Dostupno na: https://theanarchistlibrary.org/library/ken-knabb-the-joy-of-revolution (pristupljeno 19. 1. 2020.).

Kropotkin, Peter (1986): »Revolucionarna oblast«, Antologija anarhizma 1, preveli Doris Debnjak i dr., Rudi Rizman (ur.), Krtina, Ljubljana, str. 304-313.

Kurnik, Andrej (2013): »Artikulacije potrebujejo neartikuliran bes«, Časopis za kritiko znanosti, domišljijo in novo antropologijo 41 (2013) 254, str. 11-19.

Kurnik, Andrej (2005): Biopolitika. Novi družbeni boji na horizontu, Sophia, Ljubljana.

Lafargue, Paul (1980): »Pravica do lenobe«, preveo Drago B. Rotar, Časopis za kritiko znanosti, domišljijo in novo anropologijo 17 (1980) 37-38, str. 240-274.

Mahno, Nestor (1986): »Abeceda revolucionarnega anarhizma«, Antologija anarhizma 1, preveli Doris Debnjak i dr., Rudi Rizman (ur.), Krtina, Ljubljana, str. 491-504.

Marx, Karl; Engels, Friedrich (1975a): Nemška ideologija, u: Izbrana dela 2, Cankarjeva založba, Ljubljana, str. 5-352. 
Marx, Karl; Engels, Friedrich (1975b): Manifest komunistične stranke, u: Izbrana dela 2, Cankarjeva založba, Ljubljana, str. 567-631.

Marx, Karl (1975): Kritika gothskega programa, u: Izbrana dela 4, Cankarjeva založba, Ljubljana, str. 479-509.

Marx, Karl (1950): Državljanska vojna v Franciji, Cankarjeva založba, Ljubljana.

Mezzadra, Sandro; Roggero, Gigi (2007): »Singularisation of the common: Thoughts on the crisis of the 'movement of movements' «, preveli Tadzio Müller, Ben Trott, Turbulence 1. Dostupno na: http://turbulence.org.uk/turbulence-1/singularisation-of-the-common/ (pristupljeno 19. 1. 2020.).

Öcalan, Abdullah (2011): Democratic Confederalism, Transmedia Publishing Ltd., London.

Rancière, Jacques (2005): Nerazumevanje, prevela Jelica Šumič-Riha, Založba ZRC, Ljubljana.

Rancière, Jacques (2004): »Demokracija kot nujen škandal«, intervju (razgovarali Léa Gauthier, Jean-Marc Adolphe), prevela Suzana Koncut, Maska 19 (2004) 3-4, str. 46-51.

Rancière, Jacques (1995): »Politics, Identification and Subjectivization«, u: John Rajhcman (ur.), Identity in Question, Routledge, London, str. 64-70.

Reich, Wilhelm (1981): Masovna psihologija fašizma, preveli Nadežda Čačinovič-Puhovski, Žarko Puhovski, Mladost, Beograd.

Rizman, Rudi (1986): »Oris razvoja anarhistične družbene misli«, Antologija anarhizma 1, preveli Doris Debnjak i dr., Rudi Rizman (ur.), Krtina, Ljubljana, str. 21-75.

Situacionistička Internacionala (2008): Časopis Gradac (2008) 164-166, Aleksa Golijanin (ur.).

Šumič-Riha, Jelica (2007): »Jetniki Drugega, ki ne obstaja«, Filozofski vestnik 28 (2007) 1 , str. 81-100.

Vaneigem, Raoul (1965): The Revolution of Everyday Life, The Anarchist Library. Dostupno na: https://theanarchistlibrary.org/library/raoul-vaneigem-the-revolution-of-everyday-life (pristupljeno 19. 1. 2020.).

Vodovnik, Žiga (2011): »Anarhizem in tekma idej«, u: Žiga Vodovnik (ur.), Antologija anarhizma 3, Krtina, Ljubljana, str. 9-15.

Žižek, Slavoj (2007): Nasilje, Društvo za teoretsko psihoanalizo, Analecta, Ljubljana.

\title{
Lana Zdravković
}

\section{Thinking the Revolution as the Creation of Universal - Non-etatist, Non-representative, Non-identitarian - Political Space 'for All'}

\begin{abstract}
The paper considers the possibility of rethinking and practising revolutionary politics in contemporaneity, through a look at the legacy of 20th-century revolutionary thought-practice and revolutionary events in the 21 st century, which experiment with the constitution of revolutionary power without seizing the governmental power. Going from the historical situation, that the revolution "eats its children", I argue that a true revolution does not mean taking power, but on the contrary, abolishing the instance of concentrated power. The revolution must be reconceived and put on the map of history as an emancipatory process of establishing a policy of equality, which is the creation of a universal space of politics for 'all' or 'anyone' without the Other. This presupposes the conceptualisation and redefinition of the revolutionary subject, the revolutionary method, and the revolutionary organization.
\end{abstract}

\section{Keywords}

revolution, thought-practice, emancipatory politics 